\title{
Clinical Evidence and Proposed Mechanisms for Cardiovascular and Kidney Benefits from Glucagon-like Peptide-1 Receptor Agonists
}

\author{
Emily J Cox, ${ }^{1}$ Radica Z Alicic, ${ }^{1,2}$ Joshua J Neumiller, ${ }^{3}$ and Katherine R Tuttle ${ }^{1,4}$ \\ 1. Providence Medical Research Center, Providence Health and Services, Spokane, WA, USA; 2. University of Washington School of Medicine, \\ University of Washington, Spokane and Seattle, WA, USA; 3. Department of Pharmacotherapy, College of Pharmacy and Pharmaceutical Sciences, \\ Washington State University, Spokane, WA, USA; 4. Nephrology Division, Kidney Research Institute, and Institute of Translational Health Sciences, \\ University of Washington, Spokane and Seattle, WA, USA
}

DOI: https://doi.org/10.17925/USE.2020.16.2.80

\begin{abstract}
C oincident with the diabetes pandemic, diabetic complications_especially kidney disease and cardiovascular disease-have become large-scale public health problems. Glucagon-like peptide-1 (GLP-1) receptor agonists, a newer class of anti-hyperglycemic therapies, represent a major advance in the treatment of these complications in type 2 diabetes. In addition to effectively treating hyperglycemia, they have a low intrinsic risk of hypoglycemia and promote reductions in blood pressure and body weight. Furthermore, in clinical trials of GLP-1 receptor agonists, the risks of cardiovascular events and new or worsening diabetic kidney disease (DKD) were reduced. As a result, guidelines from major professional organizations now recommend GLP-1 receptor agonists for patients with type 2 diabetes, to reduce the risk of atherosclerotic cardiovascular disease or DKD. The exact mechanism behind these clinical benefits is currently under investigation, as they cannot be fully explained by the observed glycemic-lowering properties, or the modest improvements in blood pressure and weight loss caused by agents in this class. Emerging data suggest that the pro-inflammatory consequences of diabetes are a likely therapeutic target for the immunomodulatory effects of GLP-1 receptor agonists on the kidney and heart.
\end{abstract}

\section{Keywords}

Cardiovascular outcome trials, diabetic kidney disease, immunity, inflammation, recommendations

Disclosures: Radica Z Alicic received consulting fees from Boehringer Ingelheim. Joshua J Neumiller has received consulting fees from Novo Nordisk, Inc. Katherine R Tuttle has served as a consultant for Eli Lilly and Company, Boehringer Ingelheim, AstraZeneca, Gilead, Goldfinch Bio, Novo Nordisk, Bayer, and Janssen. Emily J Cox has no financial or non-financial relationships or activities to declare in relation to this article.

Review Process: Double-blind peer review.

Compliance with ethics: This study involves a review of the literature and did not involve any studies with human or animal subjects performed by any of the authors.

Authorship: The named authors meet the International Committee of Medical Journal Editors (ICMJE) criteria for authorship of this manuscript, take responsibility for the integrity of the work as a whole, and have given final approval for the version to be published.

Access: This article is freely accessible at touchENDOCRINOLOGY.com (c) Touch Medical Media 2020. Received: June 15, 2020

Accepted: July 24, 2020

Published Online: December 10, 2020

Citation: US Endocrinology. 2020;16(2):80-7

Corresponding Author: Radica Alicic, 101 W 8th Avenue Suite 6050W, Spokane, WA 99204, USA

E:Radica.Alicic@providence.org

Support: No funding was received fo

the publication of this article.
In the USA, over 30 million people-about $10 \%$ of the population-have diabetes. ${ }^{1}$ Worldwide, the number of people with diabetes has risen sharply, especially in low- and middle-income countries. One in 11 adults_about 470 million people-had diabetes in the year 2019, and 700 million cases are projected worldwide by $2045 .^{2}$ The vast majority of people with diabetes, $>95 \%$, have type 2 diabetes (T2D). Macro- and microvascular complications of T2D markedly increase morbidity and mortality. Notably, development of chronic kidney disease in diabetes, also referred to as diabetic kidney disease (DKD), compounds the already elevated risk of all-cause and cardiovascular death associated with diabetes. ${ }^{3-6}$

Glucagon-like peptide-1 (GLP-1) receptor agonists currently approved by the United States Food and Drug Administration (FDA), include exenatide, liraglutide, lixisenatide, dulaglutide, and semaglutide. The appearance of exenatide, the first-in-class GLP-1 receptor agonist to receive approval from the FDA in 2005, garnered enthusiasm about this new class of glucose-lowering medications that carried a low risk of hypoglycemia and helped patients with T2D lose weight. Shortly thereafter, in 2008, the FDA disseminated a Guidance for Industry which laid out a roadmap to conduct cardiovascular outcome trials (CVOTs) designed to assess the cardiovascular safety of newly approved glucose

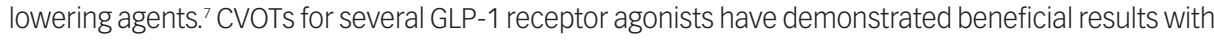
regard to primary cardiovascular disease outcomes and main secondary kidney disease outcomes. As a result, multiple professional organizations, including the American Diabetes Association (ADA), the American Association of Clinical Endocrinologists (AACE), the American College of Endocrinology (ACE), the European Association for the Study of Diabetes (EASD), and the European Society of Cardiology (ESC), now recommend GLP-1 receptor agonists for patients with T2D who are at risk of atherosclerotic cardiovascular disease and DKD..$^{8-11}$

This review discusses current evidence for use of GLP-1 receptor agonists based upon available data from clinical trials, as well as a review of plausible biological mechanisms by which GLP-1 receptor agonists convey cardiovascular and kidney protection. Additionally, it provides clinical practice recommendations for the use of GLP-1 receptor agonists in patients with T2D. 
Table 1: Summary of cardiovascular outcome trials with glucagon-like peptide-1 receptor agonists

\begin{tabular}{|c|c|c|c|c|c|c|}
\hline & $\begin{array}{l}\text { REWIND }^{14} \\
(n=9,901)\end{array}$ & $\begin{array}{l}\text { EXSCEL }^{15} \\
(n=14,752)\end{array}$ & $\begin{array}{l}\text { ELIXA }^{16} \\
(n=6,068)\end{array}$ & $\begin{array}{l}\text { LEADER }^{12} \\
(\mathrm{n}=9,340)\end{array}$ & $\begin{array}{l}\text { SUSTAIN- } 6^{17} \\
(n=3,297)\end{array}$ & $\begin{array}{l}\text { PIONEER-6 }{ }^{18} \\
(n=3,183)\end{array}$ \\
\hline Agent & Dulaglutide & Exenatide XR & Lixisenatide & Liraglutide & $\begin{array}{l}\text { Semaglutide } \\
\text { (injectable) }\end{array}$ & $\begin{array}{l}\text { Semaglutide } \\
\text { (oral) }\end{array}$ \\
\hline Median follow-up, years & 5.4 & 3.2 & 2.1 & 3.8 & 2.1 & 1.3 \\
\hline Metformin use, $\%$ & 81 & 77 & 66 & 76 & 73 & 77 \\
\hline Prior CVD, \% & 32 & 73 & 100 & 81 & 59 & 85 \\
\hline Mean baseline HbA1c, \% & 7.2 & 8.0 & 7.7 & 8.7 & 8.7 & 8.2 \\
\hline Primary outcome, HR ( $95 \% \mathrm{Cl}$ ) & $\begin{array}{l}\text { 3-point MACE } \\
0.88 \\
(0.79-0.99)\end{array}$ & $\begin{array}{l}\text { 3-point MACE } \\
0.91 \\
(0.83-1.00)\end{array}$ & $\begin{array}{l}\text { 4-point MACE } \\
1.0 \\
(0.89-1.17)\end{array}$ & $\begin{array}{l}\text { 3-point MACE } \\
0.87 \\
(0.78-0.97)\end{array}$ & $\begin{array}{l}\text { 3-point MACE } \\
0.74 \\
(0.58-0.95)\end{array}$ & $\begin{array}{l}\text { 3-point MACE } \\
0.79 \\
(0.57-1.10)^{*}\end{array}$ \\
\hline $\begin{array}{l}\text { Cardiovascular death, HR } \\
(95 \% \mathrm{Cl})\end{array}$ & $\begin{array}{l}0.91 \\
(0.78-1.06)\end{array}$ & $\begin{array}{l}0.88 \\
(0.76-1.02)\end{array}$ & $\begin{array}{l}0.98 \\
(0.78-1.22)\end{array}$ & $\begin{array}{l}0.88 \\
(0.75-1.03)\end{array}$ & $\begin{array}{l}0.98 \\
(0.65-1.48)\end{array}$ & $\begin{array}{l}0.49 \\
(0.27-0.92)\end{array}$ \\
\hline $\begin{array}{l}\text { Myocardial infarction, HR } \\
(95 \% \mathrm{Cl})\end{array}$ & $\begin{array}{l}0.96 \\
(0.79-1.16)\end{array}$ & $\begin{array}{l}0.97 \\
(0.85-1.10)\end{array}$ & $\begin{array}{l}1.03 \\
(0.87-1.22)\end{array}$ & $\begin{array}{l}0.86 \\
(0.73-1.00)\end{array}$ & $\begin{array}{l}0.74 \\
(0.51-1.08)\end{array}$ & $\begin{array}{l}1.18 \\
(0.73-1.90)\end{array}$ \\
\hline Stroke, HR (95\% Cl) & $\begin{array}{l}0.76 \\
(0.61-0.95)\end{array}$ & $\begin{array}{l}0.85 \\
(0.70-1.03)\end{array}$ & $\begin{array}{l}1.12 \\
(0.79-1.58)\end{array}$ & $\begin{array}{l}0.86 \\
(0.71-1.11)\end{array}$ & $\begin{array}{l}0.61 \\
(0.38-0.99)\end{array}$ & $\begin{array}{l}0.74 \\
(0.35-1.60)\end{array}$ \\
\hline All-cause mortality, HR $(95 \% \mathrm{Cl})$ & $\begin{array}{l}0.90 \\
(0.80-1.01)\end{array}$ & $\begin{array}{l}0.86 \\
(0.77-0.97)\end{array}$ & $\begin{array}{l}0.94 \\
(0.78-1.13)\end{array}$ & $\begin{array}{l}0.85 \\
(0.74-0.97)\end{array}$ & $\begin{array}{l}1.05 \\
(0.74-1.50)\end{array}$ & $\begin{array}{l}0.51 \\
(0.31-0.84)\end{array}$ \\
\hline
\end{tabular}

${ }^{*} p<0.001$ for non-inferiority; $p=0.17$ for superiority.

Definition of 3-point MACE: a composite of cardiovascular death, non-fatal myocardial infarction, and non-fatal stroke.

Definition of 4-point MACE: a composite of cardiovascular death, non-fatal myocardial infarction and hospitalization for unstable angina.

$\mathrm{Cl}=$ confidence interval; $C V D=$ cardiovascular disease; ELIXA = Evaluation of Lixisenatide in Acute Coronary Syndrome; EXSCEL = EXenatide Study of Cardiovascular Event Lowering;

$\mathrm{HDA} 1 \mathrm{C}=$ glycated hemoglobin; HR = hazard ratio; LEADER = Liraglutide Effect and Action in Diabetes: Evaluation of Cardiovascular Outcome Results; MACE = major adverse

cardiovascular events; PIONEER-6 = Peptide Innovation for Early Diabetes Treatment 6; REWIND = Researching Cardiovascular Events with a Weekly Incretin in Diabetes;

SUSTAIN-6 = Trial to Evaluate Cardiovascular and Other Long-term Outcomes with Semag/utide in Subjects with Type 2 Diabetes; XR = extended release.

\section{Kidney disease outcomes of clinical trials with glucagon-like peptide-1 receptor agonists}

To date, trials for liraglutide, semaglutide, exenatide, and dulaglutide have reported secondary outcomes for kidney disease in diabetic patients. For the purpose of discussing these trials, DKD is considered an interchangeable term for chronic kidney disease in diabetes and diabetic nephropathy.

\section{Liraglutide}

The LEADER (Liraglutide Effect and Action in Diabetes: Evaluation of Cardiovascular Outcome Results) CVOT enrolled patients with T2D and high cardiovascular risk, with a median follow-up duration of 3.8 years. ${ }^{12}$ Approximately $23 \%$ of participants had moderate-to-severe DKD. The primary composite cardiovascular outcome was death from cardiovascular causes, myocardial infarction, or stroke (3-point major adverse cardiovascular events [MACE]), which occurred in fewer patients receiving liraglutide (608/4,668 patients; 13\%) than in those receiving placebo (694/4,672; 15\%). The difference was statistically significant for non-inferiority (hazard ratio [HR] 0.87; 95\% confidence interval [CI] 0.78-0.97; $p<0.001)$. This finding led to a new indication for liraglutide for reducing the risk of MACE in adults with T2D and established cardiovascular disease (Table 1).12-18

Compared with placebo, liraglutide treatment was associated with a lower rate of the secondary outcome for kidney disease, a composite of new-onset macroalbuminuria, doubling of serum creatinine and creatinine clearance $<45 \mathrm{~mL} / \mathrm{min} / 1.73 \mathrm{~m}^{2}$, end-stage kidney disease, or death due to kidney disease. The kidney disease outcome occurred in 161 patients treated with liraglutide compared with 215 patients randomized to receive placebo ( $\mathrm{HR} 0.74 ; 95 \% \mathrm{Cl} 0.60-0.91 ; \mathrm{p}=0.004$; Table 2). 12,14,16,17,19
The decline in estimated glomerular filtration rate (eGFR) at 36 months was -7.4 versus $-7.8 \mathrm{~mL} / \mathrm{min} / 1.73 \mathrm{~m}^{2}$ in the liraglutide and placebo groups, respectively; showing a significantly slower decline in the liraglutide group. ${ }^{20}$ However, shorter treatment duration (26 weeks) with liraglutide did not demonstrate a beneficial effect on eGFR decline, perhaps due to insufficient observation time. ${ }^{21}$

\section{Semaglutide}

The effects of the injectable and oral formulations of semaglutide on cardiovascular and kidney outcomes were evaluated in two large CVOTs. The SUSTAIN-6 (Trial to Evaluate Cardiovascular and Other Long-term Outcomes with Semaglutide in Subjects with Type 2 Diabetes) trial enrolled patients with established cardiovascular disease, chronic kidney disease, or both. ${ }^{17}$ The median duration of follow-up for study participants was 2.1 years. Treatment with injectable semaglutide was non-inferior to placebo for the primary composite outcome of first occurrence of 3-point MACE (HR 0.74; 95\% Cl $0.58-0.95 ; p<0.001$ for non-inferiority; Table 1). In addition, semaglutide was also superior to placebo for the primary cardiovascular outcome. SUSTAIN-6 had a secondary outcome of new or worsening DKD, which was lower in the group receiving semaglutide (HR 0.64; 95\% $\mathrm{Cl} 0.46-0.88$; $\mathrm{p=0.005;} \mathrm{Table} \mathrm{2).}$ The benefit seen in the semaglutide group on new or worsening DKD was primarily driven by differences in macroalbuminuria. Based on SUSTAIN-6, injectable semaglutide was given an indication to reduce MACE in adults with T2D and established cardiovascular disease. ${ }^{22}$

The PIONEER-6 (Peptide Innovation for Early Diabetes Treatment) trial assessed the cardiovascular safety of oral semaglutide in people with T2D and cardiovascular or DKD. After a median duration of follow up of 
Table 2: Kidney outcomes in clinical trials with glucagon-like peptide-1 receptor agonists

\begin{tabular}{|c|c|c|c|c|c|}
\hline & $\begin{array}{l}\text { REWIND14 } \\
(n=9,901)\end{array}$ & $\begin{array}{l}\text { AWARD- } 7^{19} \\
(\mathrm{n}=577)\end{array}$ & $\begin{array}{l}\text { ELIXA }^{16} \\
(n=6,068)\end{array}$ & $\begin{array}{l}\text { LEADER }^{12} \\
(\mathrm{n}=9,340)\end{array}$ & $\begin{array}{l}\text { SUSTAIN-617 } \\
(\mathrm{n}=3,297)\end{array}$ \\
\hline Intervention/drugs & Dulaglutide & Dulaglutide & Lixisenatide & Liraglutide & Semaglutide \\
\hline $\begin{array}{l}\text { Secondary or } \\
\text { exploratory } \\
\text { kidney-disease } \\
\text { outcomes }\end{array}$ & $\begin{array}{l}\text { Secondary outcome: } \\
\text { Lower incidence } \\
\text { of the composite } \\
\text { endpoint (new onset } \\
\text { macroalbuminuria, } \\
\geq 30 \% \text { decline in eGFR, } \\
\text { or need for chronic } \\
\text { KRT) } 17 \% \text { in dulaglutide } \\
\text { versus } 20 \% \text { in placebo } \\
\text { group ( } p<0.001 \text { ) }\end{array}$ & 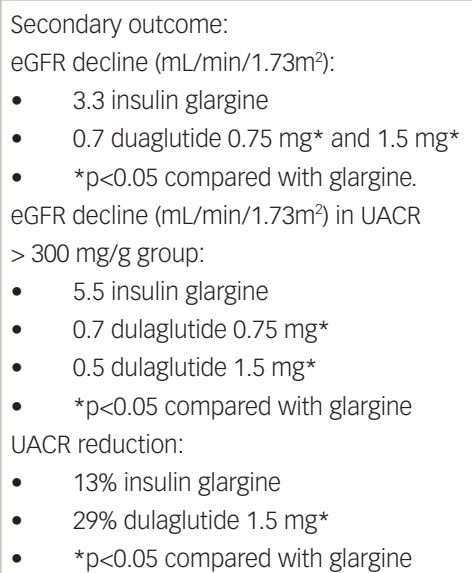 & $\begin{array}{l}\text { Prespecified analysis: } \\
\text { Change in UACR in \%: } \\
34 \% \text { in placebo versus } \\
24 \% \text { in lixisenatide } \\
\text { group ( } p=0.004) ; \\
\text { attenuated after } \\
\text { adjustment for HbA1C } \\
(p=0.07)\end{array}$ & $\begin{array}{l}\text { Secondary outcome: } \\
\text { Lower incidence } \\
\text { of composite } \\
\text { outcome (new onset } \\
\text { albuminuria, doubling } \\
\text { of } \mathrm{SCr} \text { and } \mathrm{CrCl} \\
<45 \mathrm{~mL} / \mathrm{min} \text {, need for } \\
\mathrm{KRT} \text {, death due to renal } \\
\text { causes) } \\
1.5 \text { events/100 patient// } \\
\text { year in liraglutide } \\
\text { versus } 1.9 \text { events } \\
\text { events/100 patient/ } \\
\text { year in placebo group } \\
\text { ( } \mathrm{p}=0.003 \text { ) }\end{array}$ & $\begin{array}{l}\text { Secondary outcome: } \\
\text { Lower incidence of } \\
\text { new or worsening } \\
\text { nephropathy: } \\
3.8 \% \text { in semaglutide } \\
\text { versus } 6.1 \% \text { in placebo } \\
\text { group ( } p=0.005 \text { ) } \\
\text { Lower rate of new onset } \\
\text { macroalbuminuria: } \\
2.5 \% \text { in semaglutide } \\
\text { versus } 4.9 \% \text { in placebo } \\
\text { group }\end{array}$ \\
\hline
\end{tabular}

${ }^{*}$ Clinical trial results not yet available.

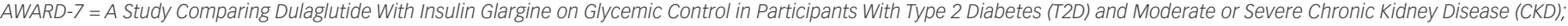
$\mathrm{CrCl}=$ creatinine clearance; $\mathrm{GFR}=$ estimated glomerular filtration rate; ELIXA = Evaluation of Lixisenatide in Acute Coronary Syndrome; KRT = kidney replacement therapy; LEADER = Liraglutide Effect and Action in Diabetes: Evaluation of Cardiovascular Outcome Results; REWIND = Researching Cardiovascular Events with a Weekly Incretin in Diabetes:

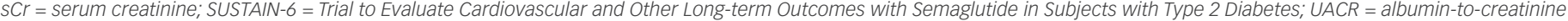
ratio (with albumin measured in milligrams and creatinine measured in grams).

1.3 years, oral semaglutide showed non-inferiority when compared with placebo for the primary composite outcome of 3-point MACE (HR 0.79; $95 \% \mathrm{Cl} 0.57-1.1 ; p<0.001$ for non-inferiority). This trial report has not yet reported kidney disease outcomes. ${ }^{18}$ To date, oral semaglutide does not carry an indication for reduction of MACE.

\section{Lixisenatide}

The ELIXA (Evaluation of Lixisenatide in Acute Coronary Syndrome) trial enrolled patients with T2D and a recent history of myocardial infarction or hospitalization for unstable angina. ${ }^{16}$ Study participants were followed within the trial for a median 2.1 years. A large proportion of participants had microalbuminuria $(1,148 / 6,068)$ or macroalbuminuria $(389 / 6,068)$. Lixisenatide proved non-inferior to placebo for the primary composite outcome of cardiovascular death, myocardial infarction, stroke, or hospitalization for unstable angina (HR 1.0; 95\% Cl 0.89-1.2; $\mathrm{p}<0.001$ ), but did not demonstrate superiority (Table 1).

An exploratory analysis of ELIXA investigated the proportional change in albuminuria and eGFR according to baseline albuminuria status and examined the time to new-onset macroalbuminuria and doubling of serum creatinine. After adjustment for traditional DKD risk factors, lixisenatide was shown to reduce progression of albuminuria in participants who were macroalbuminuric (-39\%; $95 \% \mathrm{Cl}-69$ to $-9.8 ; \mathrm{p}=0.007)$. Lixisenatide treatment was also associated with a lower risk for new onset macroalbuminuria adjusted for baseline and time-varying glycated hemoglobin (HDA1C) (HR 0.81; 95\% Cl 0.66-0.99; $\mathrm{p}=0.04$ and HR 0.82; 95\% Cl 0.66-0.99; $\mathrm{p}=0.049$, respectively), but no differences in eGFR decline were observed between treatment groups. ${ }^{23}$

\section{Exenatide}

The EXSCEL (Exenatide Study of Cardiovascular Event Lowering) trial enrolled patients with T2D with $(10,782 / 14,752 ; 73 \%)$ or without $(3,970 / 14,752 ; 27 \%)$ previous cardiovascular disease. ${ }^{15}$ The primary cardiovascular composite outcome (3-point MACE) met criteria for non-inferiority in participants on once-weekly exenatide compared with placebo; however, it did not reach statistical significance for superiority (HR 0.91; 95\% Cl 0.83-1.0; $p<0.001$ for non-inferiority; Table 1). After a median follow-up period of 3.2 years, the mean change in eGFR from baseline $\left(77 \mathrm{~mL} / \mathrm{min} / 1.73 \mathrm{~m}^{2}\right.$ in the exenatide group and $76 \mathrm{~mL} / \mathrm{min} / 1.73 \mathrm{~m}^{2}$ in the placebo group) was similar in both treatment arms. ${ }^{15,24} \mathrm{New}$-onset macroalbuminuria was noted in $2.2 \%$ and $2.5 \%$ of participants in the exenatide and placebo groups, respectively (HR 0.87; 95\% Cl 0.70-1.1; $\mathrm{p}=0.19) .{ }^{24}$ Another recently reported post-hoc analysis compared the effects of twice-daily exenatide versus titrated insulin glargine on eGFR and albuminuria in patients with T2D without overt DKD. ${ }^{18}$ This post-hoc analysis similarly did not find a beneficial effect of exenatide on eGFR decline or progression of albuminuria. ${ }^{25}$

\section{Dulaglutide}

The cardiovascular safety of dulaglutide was assessed in the REWIND (Researching Cardiovascular Events with a Weekly Incretin in Diabetes) trial. ${ }^{14}$ A total of 9,901 participants with T2D were enrolled in REWIND and followed for a median duration of 5.4 years. Notably, approximately $30 \%$ of enrolled participants in REWIND had a previous history of cardiovascular disease, with the remaining majority of participants being a "primary prevention" group with cardiovascular risk factors. REWIND additionally had a lower mean HbA1C compared with other CVOTs with GLP-1 receptor agonists (Table 1). Overall, the primary composite outcome (3-point MACE) was significantly 
reduced in participants receiving dulaglutide versus placebo (HR 0.88; 95\% Cl 0.79-0.99; $\mathrm{p}=0.026$ ). Based on findings from REWIND, dulaglutide was granted an indication to reduce the risk of MACE in adults with T2D with established cardiovascular disease or multiple cardiovascular risk factors, ${ }^{26}$ making dulaglutide the first GLP-1 receptor agonist to receive an indication for primary prevention of MACE. Because the benefits of dulaglutide in the REWIND trial were not limited to participants with an elevated HDA1C, the REWIND trial has also supported recent recommendations for use of GLP-1 receptor agonists in patients with T2D at high risk for, or with, established atherosclerotic cardiovascular disease, irrespective of baseline HDA1C or individualized HbA1c target. ${ }^{13}$

The AWARD-7 trial (A Study Comparing Dulaglutide With Insulin Glargine on Glycemic Control in Participants With Type 2 Diabetes (T2D) and Moderate or Severe Chronic Kidney Disease [CKD]) was the first clinical trial of a GLP-1 receptor agonist in patients with T2D selected for moderate-to-severe DKD (mean eGFR $38 \mathrm{~mL} / \mathrm{min} / 1.73 \mathrm{~m}^{2}$ ). Both dulaglutide treatment groups experienced less eGFR decline when compared with participants in the insulin glargine treatment group: mean eGFR decline was $-3.3 \mathrm{~mL} / \mathrm{min} / 1.73 \mathrm{~m}^{2}$ in the insulin glargine group versus $-0.7 \mathrm{~mL} / \mathrm{min} / 1.73 \mathrm{~m}^{2}$ in both higher $(1.5 \mathrm{mg}$ weekly) and lower $(0.75 \mathrm{mg}$ weekly) dose dulaglutide-treated groups. Among AWARD-7 participants with macroalbuminuria, who are at high-risk for DKD progression, a marked attenuation of eGFR decline was observed (mean $-5.5 \mathrm{~mL} / \mathrm{min} / 1.73 \mathrm{~m}^{2}$ in the insulin glargine group versus $-0.7 \mathrm{~mL} / \mathrm{min} / 1.73 \mathrm{~m}^{2}$ and $-0.5 \mathrm{~mL} / \mathrm{min} / 1.73 \mathrm{~m}^{2}$ in the dulaglutide $0.75 \mathrm{mg}$ weekly and $1.5 \mathrm{mg}$ weekly groups, respectively; Table 2). ${ }^{19}$ Notably, fewer participants in the higher dose dulaglutide group reached the composite endpoint of end-stage kidney disease or $\geq 40 \%$ eGFR decline compared with the insulin glargine group (5.2\% versus $11 \%$, $\mathrm{p}=0.038$; Table 2). ${ }^{19}$ The secondary kidney disease outcomes from REWIND support the AWARD-7 findings. In REWIND, approximately 20\% and 35\% of participants had an eGFR $<60 \mathrm{~mL} / \mathrm{min} / 1.73 \mathrm{~m}^{2}$ or microalbuminuria, respectively (Table 1). ${ }^{14}$ The main secondary kidney disease outcome included new onset macroalbuminuria, sustained decline in eGFR of $\geq 30 \%$, or end stage kidney disease. Treatment with dulaglutide compared with placebo resulted in significantly fewer participants experiencing a kidney-related event (17\% versus 20\%; $p<0.001$; Table 2).

\section{Putative mechanisms for kidney and cardiovascular benefits of glucagon-like peptide-1 receptor agonists}

Primary non-glycemic benefits of GLP-1 receptor agonist therapy are reduction of body weight and blood pressure. GLP-1 receptor agonists produce a mean weight loss of approximately $3 \mathrm{~kg}$ per available clinical trial data. ${ }^{27}$ In the CVOTs, mean systolic blood pressure was typically reduced by $3-4 \mathrm{mmHg}{ }^{28}$ Such reductions in body weight and blood pressure also contribute to cardiovascular risk reduction. Although glycemic control was improved with GLP-1 receptor agonist therapy compared with placebo in the CVOTs, glucose lowering per se in previous clinical trials for T2D did not reduce risk for major atherosclerotic cardiovascular disease events. ${ }^{29-31}$ Therefore, the clinical benefits of GLP-1 receptor agonists are not likely to be fully explained by improvements in traditional risk factors.

A plausible hypothesis is that GLP-1 receptor agonists protect the heart and kidney via anti-oxidative and anti-inflammatory effects that mitigate key mechanisms of kidney and cardiovascular damage in diabetes. ${ }^{32-35} \mathrm{It}$ is not yet determined to what extent these effects are mediated by the
GLP-1 receptor, which is expressed in many tissues, including the rodent glomerulus and the human kidney, cardiomyocytes, and autonomic nervous system tissues. (Figure 1). ${ }^{36-40}$

Diabetes is a state of ongoing inflammation arising from activation of the innate immune system, which may manifest clinically as increases in circulating immune cells and markers of inflammation. ${ }^{34,41-44}$ The circulating biomarkers are primarily mediators of the acute phase of the innate immune response, including serum amyloid A, sialic acid, C-reactive protein, and interleukin-6.5.46 Hyperglycemia correlates with higher circulating levels of inflammatory mediators, and glycemic control is associated with their reductions. ${ }^{44}$ This sustained inflammatory state is a predisposing factor for DKD, as reflected in increased urinary markers of inflammation, including $\alpha_{1}$-acid glycoprotein 1 , haptoglobin, clusterin, $\alpha_{2}$-HS-glycoprotein, and mannan-binding lectin serine protease 2.47 .48

A proposed paradigm for the pathogenesis of DKD includes a series of metabolic and hemodynamic insults instigated by the diabetic milieu that cause inflammation, fibrosis, and eventual loss of kidney function. Persistent hyperglycemia, insulin resistance, oxidative stress, and elevated production of advanced glycation end-products result in activation of the immune response early in the course of diabetes. ${ }^{32,3344}$ This immune response, in turn, drives inflammation that worsens over time, causing inflammatory cell infiltration of the kidney, and perhaps activation of the resident T-cell populations in the kidney. ${ }^{49}$ Invasion of these inflammatory cells ultimately results in upregulation of growth factors and pro-fibrotic cytokines that

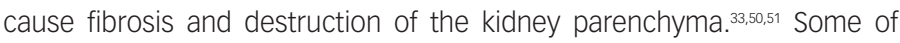
the mechanisms contributing to fibrotic deposition in the glomerulus are impaired breakdown of fibrotic proteins by matrix metalloproteinases and upregulated matrix protein production in mesangial cells.5.

GLP-1 receptor agonists reduce both the inflammatory response and oxidative stress, perhaps explaining their beneficial effect on DKD. For instance, in adults with T2D, native GLP-1 and exenatide attenuate circulating levels of a number of inflammatory and oxidative stress biomarkers (interleukin- 6 and $-1 \beta$, monocyte chemoattractant protein- 1 , adhesion molecules, prostaglandins, serum amyloid $A$, tumor necrosis factor- $\alpha$, toll-like receptors, and circulating mononuclear cells). ${ }^{53}$ In experimental DKD models, GLP-1 receptor agonist treatment exhibits anti-inflammatory and antioxidative effects, resulting in protection from endothelial injury and reduction of proteinuria. ${ }^{3854}$ A plausible explanation for these anti-inflammatory and anti-oxidative effects is inhibition of nicotinamide adenine dinucleotide phosphate oxidase by increased production of cyclic adenosine monophosphate and protein kinase A.5.56 Preclinical studies in murine and cell culture models of diabetes show that liraglutide, exedin-4, and GLP-1 reduce histological and functional damage associated with DKD by decreasing mesangial expansion, glomerular hypertrophy, proliferation of mesangial cells, and tubulointerstitial and glomerular fibrosis (Figure 1). . $35.5,57-61^{-1}$

Cardiovascular disease pathogenesis in T2D is multi-factorial and includes metabolic and hemodynamic insults as well as intracellular changes associated with activation of inflammatory signaling. The major consequences of T2D and chronic inflammation are deposition of atherosclerotic plaque, endothelial dysfunction, cardiac myocyte hypertrophy, and myocardial fibrosis. ${ }^{22}$ These, in turn, have negative effects on ventricular relaxation and contractility, as well as microvascular and macrovascular perfusion. In addition, the metabolic insults of diabetes 
Figure 1: Putative mechanisms of glucagon-like peptide-1 receptor agonist therapies on diabetic kidney disease and cardiovascular disease

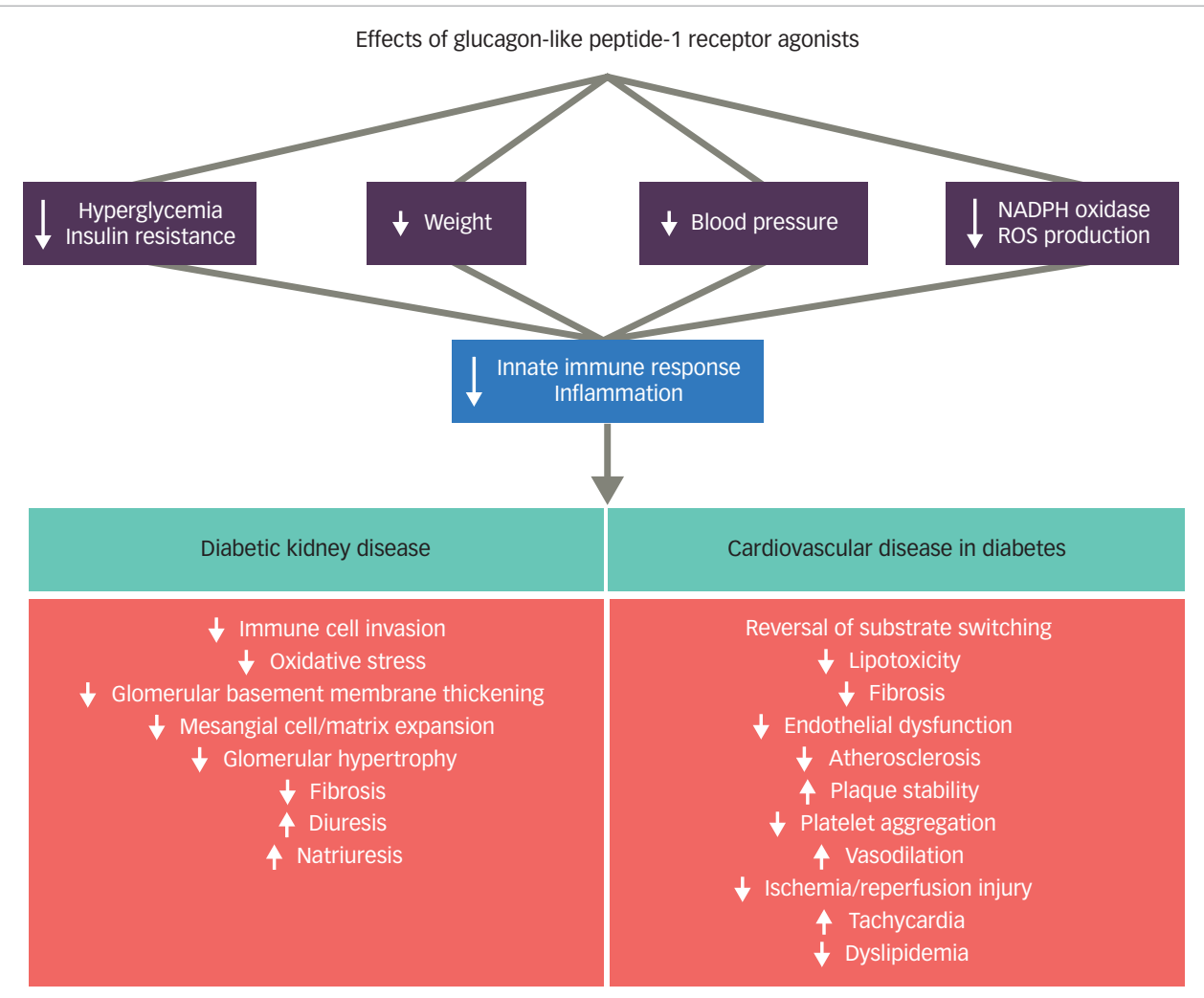

Systemic effects of glucagon-like peptide-1 (GLP-1) receptor agonist treatment include reduction of hyperglycemia, insulin resistance, body weight, blood pressure, reactive oxygen species (ROS) production, and nicotinamide adenine dinucleotide phosphate oxidase (NADPH) activity, resulting in modulation of the inflammatory response. Proposed effects in the kidney are principally related to suppression of inflammation, and specifically include suppression of oxidative stress, reduced fibrosis, and blockade of immune cell infiltration. In the heart, GLP-1 receptor agonist therapy also reduces inflammation, and appears to benefit both endothelial dysfunction and dyslipidemia. GLP-1 receptor agonist therapy also produces tachycardia. Importantly, it is unknown whether any, or all, of the above effects on the heart and vascular system are mediated via GLP-1 receptors, or whether they are mediated by other, as yet unrecognized, signaling pathways. It is likely that tachycardia is mediated by direct agonism of GLP-1 receptors expressed by cells within the autonomic nervous system.

produce impaired substrate switching in the heart, resulting in energetic deficits. ${ }^{63}$ Together, these insults predispose to heart disease.

For example, liraglutide treatment promotes autophagy in cardiomyocytes, while interactions between GLP-1 receptor agonists and the autonomic nervous system may cause tachycardia.64,65 Additionally, cardiovascular protection by GLP-1 receptor agonists has been described in both preclinical and human studies. These protective effects include reduced inflammation, improved left ventricular function, increased plaque stability, and amelioration of ischemic injury. Exenatide directly induces vasodilation in humans through stimulation of nitric oxide production in the vascular endothelium. ${ }^{66}$ Both liraglutide and semaglutide modify atherosclerotic processes in humans with T2D, and in two mouse models of atherosclerosis (the $\mathrm{APOE}^{-}$and $\mathrm{LDLr}^{-1}$ models). ${ }^{67}$ Anti-atherosclerotic effects of liraglutide observed in mice include blocking low-density lipoprotein uptake and foam cell development. ${ }^{8}$ Studies on non-diabetic rats and isolated rodent hearts demonstrate reduced infarct size, increased glucose uptake by myocardial cells, and reduction of ventricular pressure with infusion of GLP-1 receptor agonists. ${ }^{69-71}$

Similarly, in ex vivo ischemia reperfusion experiments, GLP-1 receptor agonist infusions demonstrate rapid cardioprotection. ${ }^{72,73}$ Several clinical studies confirmed these findings in patients with acute ST-segment elevation infarct. Treatment with exenatide and liraglutide decreased infarct size, with evidence of improved left ventricular function as assessed by echocardiography or cardiac magnetic response imaging after 38 days to 3 months. ${ }^{74-76}$

\section{Current clinical use of glucagon-like peptide-1 receptor agonists}

GLP-1 receptor agonists are highly effective glucose-lowering agents in T2D, the original indication for their development. The ADA, EASD, ESC, and other professional organizations recommend GLP-1 receptor agonists as an option for patients not meeting individualized glycemic goals to reduce hyperglycemia and $\mathrm{HbA} 1 \mathrm{C}$. The GLP-1 receptor agonist class is also a preferred option for patients with T2D who have a need to minimize hypoglycemia or to minimize weight gain or promote weight loss. Notably, the ADA additionally recommends a GLP-1 receptor agonist in preference to insulin for patients with T2D who require greater glucose lowering than can be achieved with oral agents. ${ }^{8}$ They also recommend a "GLP-1 receptor agonist with good efficacy for weight loss" for weight reduction. Based on weight loss observed in clinical trials, the following hierarchy is recommended: semaglutide $>$ liraglutide $>$ dulaglutide $>$ exenatide $>$ lixisenatide. It is worth noting that liraglutide (marketed as Saxenda ${ }^{\circledR}$, Novo Nordisk, Plainsboro, NJ, 
Table 3: Labeled indications and dosing for currently available glucagon-like peptide-1 receptor agonists

\begin{tabular}{|c|c|c|c|c|c|c|c|}
\hline & \multicolumn{2}{|l|}{ Short-acting agents } & \multicolumn{5}{|l|}{ Long-acting agents } \\
\hline & Exenatide $^{79}$ & Lixisenatide $^{80}$ & Dulaglutide $^{26}$ & Exenatide $\mathrm{XR}^{81}$ & Liraglutide $^{82}$ & $\begin{array}{l}\text { Semaglutide } \\
\text { (injectable) }^{22}\end{array}$ & $\begin{array}{l}\text { Semaglutide } \\
\text { (oral) }^{83}\end{array}$ \\
\hline Indication(s) & $\begin{array}{l}\text { Adjunct to diet and } \\
\text { exercise to improve } \\
\text { glycemic control } \\
\text { in T2D }\end{array}$ & $\begin{array}{l}\text { Adjunct to diet } \\
\text { and exercise to } \\
\text { improve glycemic } \\
\text { control in T2D }\end{array}$ & $\begin{array}{l}\text { - Adjunct to diet } \\
\text { and exercise } \\
\text { to improve } \\
\text { glycemic } \\
\text { control in T2D } \\
\text { - To reduce the } \\
\text { risk of MACE } \\
\text { in adults } \\
\text { with T2D and } \\
\text { established } \\
\text { CVD or } \\
\text { multiple } \\
\text { cardiovascular } \\
\text { risk factors }\end{array}$ & $\begin{array}{l}\text { Adjunct to diet and } \\
\text { exercise to improve } \\
\text { glycemic control } \\
\text { in T2D }\end{array}$ & $\begin{array}{l}\text { - Adjunct to diet } \\
\text { and exercise to } \\
\text { improve glycemic } \\
\text { control in T2D } \\
\text { - To reduce the risk } \\
\text { of MACE in adults } \\
\text { with T2D and } \\
\text { established CVD }\end{array}$ & $\begin{array}{l}\text { - Adjunct to diet and } \\
\text { exercise to improve } \\
\text { glycemic control in } \\
\text { T2D } \\
\text { - To reduce the risk of } \\
\text { MACE in adults with } \\
\text { T2D and established } \\
\text { CVD }\end{array}$ & $\begin{array}{l}\text { Adjunct to diet and } \\
\text { exercise to improve } \\
\text { glycemic control } \\
\text { in T2D }\end{array}$ \\
\hline $\begin{array}{l}\text { Administration } \\
\text { frequency }\end{array}$ & Twice daily & Once daily & Once weekly & Once weekly & Once daily & Once weekly & Once daily \\
\hline $\begin{array}{l}\text { Recommended } \\
\text { dosing }\end{array}$ & $\begin{array}{l}\text { Initiate at } 5 \mu \mathrm{g} \text { twice } \\
\text { daily, then increase } \\
\text { to } 10 \mu \mathrm{g} \text { twice } \\
\text { daily after } 1 \text { month } \\
\text { according to clinical } \\
\text { response }\end{array}$ & $\begin{array}{l}\text { Initiate at } 10 \mu \mathrm{g} \\
\text { once daily for } \\
14 \text { days, then } \\
\text { increase to } 20 \mu \mathrm{g} \\
\text { daily }\end{array}$ & $\begin{array}{l}\text { - Initiate at } \\
0.75 \mathrm{mg} \text { once } \\
\text { weekly } \\
\text { - May increase } \\
\text { to } 1.5 \mathrm{mg} \text { for } \\
\text { additional } \\
\text { glycemic } \\
\text { control }\end{array}$ & $\begin{array}{l}\text { Administer } 2 \text { mg } \\
\text { once weekly }\end{array}$ & $\begin{array}{l}\text { - Initiate at } \\
0.6 \text { mg per day } \\
\text { for } 1 \text { week, then } \\
\text { increase to } \\
1.2 \mathrm{mg} \\
\text { - May increase } \\
\text { to } 1.8 \mathrm{mg} \text { for } \\
\text { additional } \\
\text { glycemic control }\end{array}$ & $\begin{array}{l}\text { - Initiate at } 0.25 \mathrm{mg} \\
\text { once weekly, then, } \\
\text { after } 4 \text { weeks, } \\
\text { increase to } 0.5 \mathrm{mg} \\
\text { once weekly } \\
\text { - } \text { May increase to } \\
1 \text { mg for additional } \\
\text { glycemic control }\end{array}$ & $\begin{array}{l}\text { - Initiate at } 3 \mathrm{mg} \\
\text { once daily for } \\
30 \text { days, then } \\
7 \text { mg once daily } \\
\text { - May increase to } \\
14 \text { mg once daily } \\
\text { for additional } \\
\text { glycemic control }\end{array}$ \\
\hline $\begin{array}{l}\text { Administration } \\
\text { timing }\end{array}$ & $\begin{array}{l}\text { Take within } \\
60 \text { minutes before } \\
\text { meals }\end{array}$ & \begin{tabular}{|l|} 
Take within \\
60 minutes before \\
morning meal
\end{tabular} & $\begin{array}{l}\text { Take on the same } \\
\text { day each week }\end{array}$ & $\begin{array}{l}\text { Take on the same } \\
\text { day each week }\end{array}$ & $\begin{array}{l}\text { Take at the same } \\
\text { time each day }\end{array}$ & $\begin{array}{l}\text { Take on the same day } \\
\text { each week }\end{array}$ & $\begin{array}{l}\text { Take at least } \\
30 \text { minutes before } \\
\text { breakfast* }\end{array}$ \\
\hline $\begin{array}{l}\text { Kidney dose } \\
\text { adjustment }\end{array}$ & $\begin{array}{l}\text { - Not } \\
\text { recommended } \\
\text { with } \mathrm{CrCl} \\
<30 \mathrm{~mL} / \mathrm{min} \\
\text { - } \text { Caution } \\
\text { recommended } \\
\text { with initiating or } \\
\text { escalating the } \\
\text { dose with } \mathrm{CrCl} \\
30-50 \mathrm{~mL} / \mathrm{min}\end{array}$ & $\begin{array}{l}\text { Not recommended } \\
\text { with } \mathrm{CrCl} \\
<15 \mathrm{~mL} / \mathrm{min}\end{array}$ & $\begin{array}{l}\text { No dosage } \\
\text { adjustments } \\
\text { recommended }\end{array}$ & $\begin{array}{l}\text { - Not } \\
\text { recommended } \\
\text { with } \mathrm{CrCl} \\
<30 \mathrm{~mL} / \mathrm{min} \\
\text { - Caution } \\
\text { recommended } \\
\text { with initiating or } \\
\text { escalating the } \\
\text { dose with } \mathrm{CrCl} \\
30-50 \mathrm{~mL} / \mathrm{min}\end{array}$ & $\begin{array}{l}\text { No dosage } \\
\text { adjustments } \\
\text { recommended }\end{array}$ & $\begin{array}{l}\text { No dosage adjustments } \\
\text { recommended }\end{array}$ & $\begin{array}{l}\text { No dosage } \\
\text { adjustments } \\
\text { recommended }\end{array}$ \\
\hline
\end{tabular}

*To be taken at least 30 minutes before the first food, beverage, or other oral medications of the day with no more than 4 ounces of plain water only (as per product label).

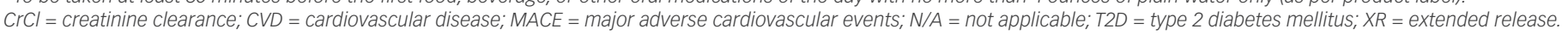

USA) carries an additional indication from the FDA for use as an adjunct to a reduced-calorie diet and increased physical activity for chronic weight management in adults who are overweight or obese. ${ }^{77}$

When considering a glucose-lowering agent in a patient with T2D, the first recommended consideration, per the 2020 ADA Standards of Medical Care in Diabetes and the EASD/ESC Consensus Statement, is whether or not the patient has indicators of high-risk or established atherosclerotic cardiovascular disease (ASCVD), DKD, or heart failure., 81,78 If a patient does meet these criteria, it is recommended that an agent with evidence for cardiovascular or DKD risk reduction be considered independent of the patient's current $\mathrm{HbA} 1 \mathrm{c}$ or individualized HbA1c target. Notably, this recommendation is stated as actionable whenever one or more of these comorbidities arise. ASCVD is considered to predominate if a patient has established ASCVD or if they have indicators of high ASCVD risk (defined by the ADA as being $>55$ years of age with coronary, carotid, or lower extremity artery stenosis of $>50 \%$ or with left ventricular hypertrophy). In patients who meet these criteria, the use of a GLP-1 receptor agonist or a sodium-glucose cotransporter-2 (SGLT2) inhibitor with proven cardiovascular benefit is preferred (Table 1). Within the ADA Standards of Care, agents with "proven cardiovascular benefit" are operationally defined as those with a labeled indication for reducing cardiovascular events. Liraglutide, dulaglutide, and subcutaneous semaglutide are the only GLP-1 receptor agonists currently with a labeled indication to reduce the 
risk of MACE, although several other GLP-1 receptor agonists have reported benefits on MACE and other cardiovascular-related outcomes (Table 1).

For patients with DKD, the use of an SGLT2 inhibitor is preferentially recommended by the ADA, EASD, and ESC. If an SGLT2 inhibitor cannot be taken, due to a contraindication, intolerance, or low eGFR, a GLP-1 receptor agonist is recommended. These recommendations apply particularly to patients with an eGFR of 30-60 mL/min/1.73 $\mathrm{m}^{2}$ and a urinary albumin-to-creatinine ratio $>30 \mathrm{mg} / \mathrm{g}$ according to the ADA. ${ }^{8}$ GLP-1 receptor agonists address multiple clinical considerations important for patients with DKD including kidney protection, along with safe and effective glycemic control, body weight loss, and cardiovascular risk reduction. In addition, it is also key to consider which agent(s) may best align with the lifestyle of a given patient (e.g., dosing frequency, subcutaneous injection versus oral administration). Safety and tolerability should also be considered based on the risks and potential benefits of alternative treatment approaches. Table 3 provides a summary of FDA-approved indications and administration considerations for currently available GLP-1 receptor agonist products. ${ }^{22,26,79-83}$

In summary, a patient-centered approach should guide the selection of GLP-1 receptor agonists for patients with T2D. Key considerations include:

- risks of hypoglycemia, DKD, and cardiovascular disease;

- impact on body weight;

- cost and availability;
- side effect profile; and

- patient preferences.
In patients with T2D who need greater glucose lowering than can be obtained with oral agents, GLP-1 receptor agonists are preferred to insulin when possible. A GLP-1 receptor agonist with demonstrated cardiovascular benefit is recommended independent of $\mathrm{HbA} 1 \mathrm{C}$ among those who have atherosclerotic cardiovascular disease. In patients with DKD, a GLP-1 receptor agonist may be used to safely and effectively treat hyperglycemia while also reducing albuminuria and eGFR decline. The medication regimen and medication-taking behavior should be reevaluated at regular intervals (every 3-6 months) and adjusted as needed to incorporate patient-specific factors that impact the choice of treatment.

\section{Conclusions}

Recommendations for clinical use of GLP-1 receptor agonists among patients with $\mathrm{T} 2 \mathrm{D}$ are evolving rapidly, reflecting data emerging from numerous clinical trials. GLP-1 receptor agonists reduce risks of both atherosclerotic cardiovascular disease and DKD. There are likely to be direct receptor-mediated mechanisms of protection in the heart and kidney, as well as indirect effects related to reducing hyperglycemia, body weight, and blood pressure. Research supporting the use of GLP-1 receptor agonists is rapidly developing and could further expand the use of these agents to indications such as kidney disease and cardiovascular disease in individuals with and without diabetes. $\square$
1. Centers for Disease Control and Prevention. National Diabetes tatistics Report 2020: Estimates of Diabetes and Its Burde in the United States. Available at: www.cdc.gov/diabetes/pdfs/ data/statistics/national-diabetes-statistics-report.Pdf (accessed August 29, 2020)

2. International Diabetes Federation. IDF Diabetes Atlas: Ninth Edition 2019. Available at: https://www.diabetesatlas.org/en/ (accessed August 29, 2020)

3. Afkarian M, Sachs MC, Kestenbaum B, et al. Kidney disease and increased mortality risk in type 2 diabetes. J Am Soc Nephrol. 2013;24:302-8

4. Einarson TR, Acs A, Ludwig C, Panton UH. Prevalence of cardiovascular disease in type 2 diabetes: a systematic literature review of scientific evidence from across the world in 2007-2017. Cardiovasc Diabetol. 2018:17:83.

5. Sarwar N, Gao P, Seshasai SRK, Gobin R. Diabetes mellitus, fasting blood glucose concentration, and risk of vascular disease: a collaborative meta-analysis of 102 prospective studies Lancet. 2010;375:2215-22.

6. Kengne AP, Turnbull F, MacMahon S. The Framingham Study, diabetes mellitus and cardiovascular disease: turning back the clock. Prog Cardiovasc Dis. 2010;53:45-51.

7. US Food and Drug Administration. Guidance for industry on diabetes mellitus-evaluating cardiovascular risk in new antidiabetic therapies to treat type 2 diabetes, 2008. Available at: www.federalregister.gov/documents/2008/12/19/E8-30086/ guidance-for-industry-on-diabetes-mellitus-evaluatingcardiovascular-risk-in-new-antidiabetic (accessed August 29, 2020)

8. American Diabetes Association. 9. Pharmacologic approaches to glycemic treatment: standards of medical care in diabetes-2020 Diabetes Care. 2020;43(Suppl. 1):S98-110.

9. Buse JB, Wexler DJ, Tsapas A, et al. 2019 Update to: Management of Hyperglycemia in Type 2 Diabetes, 2018. A Consensus Report by the American Diabetes Association (ADA) and the European Association for the Study of Diabetes (EASD). Diabetes Care. 2020;43:487-93.

10. Garber AJ, Handelsman $Y$, Grunberger G, et al. Consensus statement by the American Association of Clinical Endocrinologists and American College of Endocrinology on the comprehensive type 2 diabetes management algorithm - 2020 executive summary. Endocr Pract. 2020:26:107-39.

11. Cosentino F, Grant PJ, Aboyans V, et al. 2019 ESC Guidelines on diabetes, pre-diabetes, and cardiovascular diseases developed in collaboration with the EASD. Eur Heart J. 2020;41:255-323.

12. Marso SP, Daniels GH, Brown-Frandsen K, et al. Liraglutide and cardiovascular outcomes in type 2 diabetes. N Engl I Med. 2016;375:311-22

13. American Diabetes Association. 10. Cardiovascular disease and risk management: standards of medical care in diabetes-2020. Diabetes Care. 2020;43(Suppl. 1):S111-34.
14. Gerstein HC, Colhoun HM, Dagenais GR, et al. Dulaglutide and cardiovascular outcomes in type 2 diabetes (REWIND): double-blind, randomised placebo-controlled trial. Lancet. 2019;394:121-30.

15. Holman RR, Bethel MA, Mentz RJ, et al. Effects of once-weekly exenatide on cardiovascular outcomes in type 2 diabetes. N Engl J Med. 2017;377:1228-39.

16. Pfeffer MA, Claggett $B$, Diaz $R$, et al. Lixisenatide in patients with type 2 diabetes and acute coronary syndrome. N Eng/ I Med. 2015;373:2247-57.

17. Marso SP, Bain SC, Consoli A, et al. Semaglutide and cardiovascular outcomes in patients with type 2 diabetes. N Engl J Med. 2016;375:1834-44.

18. Husain M, Birkenfeld AL, Donsmark M, et al. Oral semaglutide and cardiovascular outcomes in patients with type 2 diabetes. N Eng/ J Med. 2019:381:841-51

19. Tuttle KR, Lakshmanan M, Rayner B, et al. CKD outcomes in type diabetes and moderate-to-severe CKD treated with dulaglutide versus insulin glargine: AWARD-7. Presented at: the American Society of Nephrology Kidney Week, San Diego, CA, October 23-28, 2018.

20. Mann JFE, Orsted DD, Brown-Frandsen K, et al. Liraglutide and renal outcomes in type 2 diabetes. N Eng/ J Med. 2017;377:839-48.

21. Davies MJ, Bain SC, Atkin SL, et al. Efficacy and safety of liraglutide versus placebo as add-on to glucose-lowering therapy in patients with type 2 diabetes and moderate renal impairment (LIRA-RENAL): a randomized clinical trial. Diabetes Care. 2016;39:222-30.

22. Semaglutide (Ozempic $\left.{ }^{\circledast}\right)$ injection. Prescribing information. Novo Nordisk, Inc.; 2020. Available at: www.novo-pi.com/ozempic.pdf (accessed November 12, 2020)

23. Muskiet MHA, Tonneijck L, Huang $Y$, et al. Lixisenatide and renal outcomes in patients with type 2 diabetes and acute coronary syndrome: an exploratory analysis of the ELIXA randomised, placebo-controlled trial. Lancet Diabetes Endocrino 2018;6:859-69

24. Bethel MA, Mentz RJ, Merrill P, et al. Microvascular and cardiovascular outcomes according to renal function in patients treated with once-weekly exenatide: insights from the EXSCEL trial. Diabetes Care. 2019:43:446-52

25. Muskiet MHA, Bunck MC, Heine RJ, et al. Exenatide twice-daily does not affect renal function or albuminuria compared to titrated insulin glargine in patients with type 2 diabetes mellitus: A post-hoc analysis of a 52-week randomised trial. Diabetes Res Clin Pract. 2019;153:14-22.

26. Dulaglutide (Trulicity®) injection. Prescribing information. Eli Lilly and Company; 2020. Available at: https://pi.lilly.com/us/ trulicity-uspi.pdf (accessed November 12, 2020).

27. Vilsboll $T$, Christensen $M$, Junker $A E$, et al. Effects of glucagon-like peptide-1 receptor agonists on weight loss: systematic review and meta-analyses of randomised controlled trials.
BMJ. 2012;344:d7771.

28. Htike ZZ, Zaccardi F, Papamargaritis D, et al. Efficacy and safety of glucagon-like peptide-1 receptor agonists in type 2 diabetes: a systematic review and mixed-treatment comparison analysis. Diabetes Obes Metab. 2017;19:524-36.

29. Group AC, Patel A, MacMahon S, et al. Intensive blood glucose control and vascular outcomes in patients with type 2 diabetes. N Eng/ J Med. 2008;358:2560-72.

30. Action to Control Cardiovascular Risk in Diabetes Study Group; Gerstein HC, Miller ME, Byington RP, et al. Effects of intensive glucose lowering in type 2 diabetes. N Engl I Med. 2008;358:2545-59

31. Duckworth W, Abraira C, Moritz T, et al. Glucose control and vascular complications in veterans with type 2 diabetes. N Eng/ J Med. 2009:360:129-39.

32. Alicic RZ, Johnson EJ, Tuttle KR. Inflammatory mechanisms as new biomarkers and therapeutic targets for diabetic kidney disease. Adv Chronic Kidney Dis. 2018;25:181-91.

33. Alicic RZ, Rooney MT, Tuttle KR. Diabetic kidney disease: challenges, progress, and possibilities. Clin J Am Soc Nephrol. 2017;12:2032-45.

34. Lopez-Candales A, Hernandez Burgos PM, Hernandez-Suarez DF, Harris D. Linking chronic inflammation with cardiovascular disease: from normal aging to the metabolic syndrome. J Nat SCi. 2017:3:e341.

35. Yaribeygi $H$, Maleki $M$, Sathyapalan $T$, et al. Anti-inflammatory potentials of incretin-based therapies used in the management of diabetes. Life Sci. 2019;241:117152.

36. Mima A, Hiraoka-Yamomoto J, Li Q, et al. Protective effects of GLP-1 on glomerular endothelium and its inhibition by PKCbeta activation in diabetes. Diabetes. 2012;61:2967-79.

37. Fan Y, Yi Z, D'Agati VD, et al. Comparison of kidney transcriptomic profiles of early and advanced diabetic nephropathy reveals potential new mechanisms for disease progression. Diabetes. 2019;68:2301-14

38. Park CW, Kim HW, Ko SH, et al. Long-term treatment of glucagon-like peptide-1 analog exendin-4 ameliorates diabetic nephropathy through improving metabolic anomalies in $\mathrm{db} / \mathrm{db}$ mice. J Am Soc Nephrol. 2007;18:1227-38.

39. Heuvelman VD, Van Raalte DH, Smits MM. Cardiovascular effects of GLP-1 receptor agonists: from mechanistic studies in humans to clinical outcomes. Cardiovasc Res. 2020;116:916-30.

40. Baggio LL, Yusta B, Mulvihill EE, et al. GLP-1 receptor expression within the human heart. Endocrinology. 2018;159:1570-84

41. Tuttle KR. Linking metabolism and immunology: diabetic nephropathy is an inflammatory disease. J Am Soc Nephrol. 2005;16:1537-8.

42. Pichler R, Afkarian M, Dieter BP, Tuttle KR. Immunity and inflammation in diabetic kidney disease: translating mechanisms to biomarkers and treatment targets. Am J Physiol Renal Physiol. 2017;312:F716-31. 
43. Matoba K, Takeda Y, Nagai Y, et al. Unraveling the role of inflammation in the pathogenesis of diabetic kidney disease. Int J MOl Sci. 2019;20:3393.

44. Pickup JC. Inflammation and activated innate immunity in the pathogenesis of type 2 diabetes. Diabetes Care. 2004;27:813-23.

45. Crook MA, Tutt P, Simpson H, Pickup JC. Serum sialic acid and acute phase proteins in type 1 and type 2 diabetes mellitus. Clin Chim Acta. 1993:219:131-8.

46. Pickup JC, Mattock MB, Chusney GD, Burt D. NIDDM as a disease of the innate immune system: association of acute-phase reactants and interleukin-6 with metabolic syndrome X. Diabetologia. 1997;40:1286-92.

47. Navarro-Gonzalez JF, Mora-Fernandez C. The role of inflammatory cytokines in diabetic nephropathy. J Am Soc Nephrol. 2008; 19:433-42.

48. Van JA, Scholey JW, Konvalinka A. Insights into diabetic kidney disease using urinary proteomics and bioinformatics. J Am SOC Nephrol. 2017;28:1050-61.

49. Turner JE, Becker M, Mittrucker HW, Panzer U. Tissue-resident lymphocytes in the kidney. J Am Soc Nephrol. 2018;29:389-99.

50. Lee SB, Kalluri R. Mechanistic connection between inflammation and fibrosis. Kidney Int Suppl. 2010;119:S22-6.

51. Meng XM, Nikolic-Paterson DJ, Lan HY. Inflammatory processes in renal fibrosis. Nat Rev Nephrol. 2014;10:493-503.

52. Qian Y, Feldman E, Pennathur S, et al. From fibrosis to sclerosis: mechanisms of glomerulosclerosis in diabetic nephropathy. Diabetes. 2008;57:1439-45.

53. Hogan AE, Gaoatswe G, Lynch L, et al. Glucagon-like peptide 1 analogue therapy directly modulates innate immune-mediated inflammation in individuals with type 2 diabetes mellitus. Diabetologia. 2014;57:781-4.

54. Kodera R, Shikata K, Kataoka HU, et al. Glucagon-like peptide-1 receptor agonist ameliorates renal injury through its anti-inflammatory action without lowering blood glucose level in a rat model of type 1 diabetes. Diabetologia. 2011;54:965-78.

55. Jha JC, Gray SP, Barit D, et al. Genetic targeting or pharmacologic inhibition of NADPH oxidase nox4 provides renoprotection in long-term diabetic nephropathy. J Am SOC Nephrol. 2014;25:1237-54

56. Dieter BP, Alicic RZ, Tuttle KR. GLP-1 receptor agonists in diabetic kidney disease: from the patient-side to the bench-side. $A m$ । Physiol Renal Physiol. 2018;315:F1519-25.

57. Hendarto H, Inoguchi T, Maeda Y, et al. GLP-1 analog liraglutide protects against oxidative stress and albuminuria in streptozotocin-induced diabetic rats via protein kinase A-mediated inhibition of renal NAD(P)H oxidases. Metabolism. 2012:61:1422-34

58. Sancar-Bas S, Gezginci-Oktayoglu S, Bolkent S. Exendin-4 attenuates renal tubular injury by decreasing oxidative stress and inflammation in streptozotocin-induced diabetic mice. Growth
Factors. 2015;33:419-29.

59. Ishibashi Y, Nishino Y, Matsui T, et al. Glucagon-like peptide-1 suppresses advanced glycation end product-induced monocyte chemoattractant protein-1 expression in mesangial cells by reducing advanced glycation end product receptor level. Metabolism. 2011:60:1271-7.

60. Tian L, Gao J, Hao J, et al. Reversal of new-onset diabetes through modulating inflammation and stimulating beta-cell replication in nonobese diabetic mice by a dipeptidyl peptidase IV inhibitor. Endocrinology. 2010;151:3049-60

61. Moschovaki Filippidou F, Kirsch AH, Thelen M, et al. Glucagon-like peptide-1 receptor agonism improves nephrotoxic serum nephritis by inhibiting T-cell proliferation. Am J Pathol. 2020;190:400-11.

62. Low Wang CC, Hess CN, Hiatt WR, Goldfine AB. Clinical update: cardiovascular disease in diabetes mellitus: atherosclerotic cardiovascular disease and heart failure in type 2 diabetes mellitus - mechanisms, management, and clinical considerations. Circulation. 2016;133:2459-502

63. Williams $\sqcup$, Nye BG, Wende AR. Diabetes-related cardiac dysfunction. Endocrinol Metab (Seoul). 2017:32:171-9.

64. Baggio LL, Ussher JR, MCLean BA, et al. The autonomic nervous system and cardiac GLP-1 receptors control heart rate in mice. Mol Metab. 2017;6:1339-49.

65. Yu W, Zha W, Ren J. Exendin-4 and liraglutide attenuate glucose toxicity-induced cardiac injury through mTOR/ULK1-dependent autophagy. Oxid Med Cell Longev. 2018;2018:5396806

66. Koska J, Sands M, Burciu C, et al. Exenatide protects against glucose- and lipid-induced endothelial dysfunction: evidence for direct vasodilation effect of GLP-1 receptor agonists in humans. Diabetes. 2015;64:2624-35.

67. Rakipovski G, Rolin B, Nohr J, et al. The GLP-1 analogs liraglutide and semaglutide reduce atherosclerosis in $\mathrm{ApOE}(-/-)$ and $\operatorname{LDLr}(-/-)$ mice by a mechanism that includes inflammatory pathways. JACC Basic Trans/ Sci. 2018;3:844-57.

68. Tashiro Y, Sato K, Watanabe T, et al. A glucagon-like peptide-1 analog liraglutide suppresses macrophage foam cell formation and atherosclerosis. Peptides. 2014;54:19-26.

69. Aravindhan $\mathrm{K}$, Bao W, Harpel MR, et al. Cardioprotection resulting from glucagon-like peptide-1 administration involves shifting metabolic substrate utilization to increase energy efficiency in the rat heart. PLOS One. 2015;10:e0130894.

70. Noyan-Ashraf MH, Momen MA, Ban K, et al. GLP-1R agonist liraglutide activates cytoprotective pathways and improves outcomes after experimental myocardial infarction in mice. Diabetes. 2009;58:975-83.

71. Wohlfart P, Linz W, Hubschle T, et al. Cardioprotective effects of lixisenatide in rat myocardial ischemia-reperfusion injury studies J Trans/ Med. 2013;11:84.
72. Ussher JR, Drucker DJ. Cardiovascular biology of the incretin system. Endocr Rev. 2012;33:187-215.

73. Ussher JR, Drucker DJ. Cardiovascular actions of incretin-based therapies. Circ Res. 2014;114:1788-803.

74. Chen WR, Hu SY, Chen YD, et al. Effects of liraglutide on left ventricular function in patients with ST-segment elevation myocardial infarction undergoing primary percutaneous coronary intervention. Am Heart J. 2015:170:845-54.

75. Lonborg J, Vejlstrup N, Kelbaek H, et al. Exenatide reduces reperfusion injury in patients with ST-segment elevation myocardial infarction. Eur Heart J. 2012;33:1491-9.

76. Woo JS, Kim W, Ha SJ, et al. Cardioprotective effects of exenatide in patients with ST-segment-elevation myocardial infarction undergoing primary percutaneous coronary intervention: results of exenatide myocardial protection in revascularization study. Arterioscler Thromb Vasc Biol. in revascularization

77. Liraglutide (Saxenda ${ }^{\oplus}$ ) injection. Prescribing information. Novo Nordisk, Inc.; 2020. Available at: www.novo-pi.com/saxenda.pd (accessed November 12, 2020).

78. American Diabetes Association, European Association for the Study of Diabetes. 2019 update to: Management of hyperglycaemia in type 2 diabetes, 2018. A consensus report by the American Diabetes Association (ADA) and the European Association for the Study of Diabetes (EASD), 2019. Available at: https://diabetologia-journal.org/ diabetologia_reviews/2019-update-to-management-ofhyperglycaemia-in-type-2-diabetes-2018-a-consensus-reportby-the-american-diabetes-association-ada-and-the-europeanassociation-for-the-study-of-diabetes-easd-pub/ (accessed August 29, 2020).

79. Exenatide (Byetta ${ }^{\circledR}$ ) injection. Prescribing information. AstraZeneca Pharmaceuticals LP: 2020. Available at: www.azpicentral.com/ pi.html?product=byetta\&country=us\&popup=no (accessed November 12, 2020)

80. Lixisenatide (Adlyxin $\left.{ }^{\oplus}\right)$ injection. Prescribing information. Sanofi-aventis US; 2019. Available at: http://products.sanofi.us/ Adlyxin/Adlyxin.pdf (accessed November 12, 2020).

81. Exenatide extended-release (Bydureon ${ }^{\circledR}$ ) injectable suspension Prescribing information. AstraZeneca Pharmaceuticals LP; 2020 Available at: www.azpicentral.com/bydureon_bcise/bydureon_ bcise.pdf\#page=1 (accessed November 12, 2020)

82. Liraglutide (Victoza ${ }^{\oplus}$ ) injection. Prescribing information. Novo Nordisk, Inc.; 2020. Available at: www.novo-pi.com/victoza.pdf (accessed November 12, 2020)

83. Semaglutide (Rybelsus ${ }^{\circledR}$ ) tablets. Prescribing information. Novo Nordisk, Inc:; 2020. Available at: www.novo-pi.com/rybelsus.pdf (accessed August 29, 2020). 